\title{
The Aspects of Judicial Supervision of General Council in Justice Administrative Court Over Governmental Regulations
}

\author{
Seyed Mohammad Sadegh Ahmadi
}

Law group director from Islamic Azad University, Isfahan Branch

Mohammad Sadegh Rafiee

Corresponding Author: PhD student in the field of public law, Islamic Azad University, Isfahan Branch (Khurasgan)

Doi:10.5901/mjss.2015.v6n6s6p216

\begin{abstract}
The presence of judicial supervision over administrative activities of government is deemed as one of the criteria for realization of law-centered government and this is a right for citizens to be allowed to complain against decisions made by administrative authorities and the administrative judge shall address them and with annulment of illegal decisions measures of administrative authority he may pave the way for guarantee of rights and freedoms of nation that is one of the objectives in basic law. The articles 170 and 173 of Islamic Republic of Iran (IRI) Constitution realized judicial supervision over administrative activities of government with establishment of an institution called justice administrative court in domestic legal system. The first clause of articles 12 and 80 in regulations of this court include the paramount legal articles regarding the aspects of annulment of governmental approvals by general council in justice administrative court. It may be implied that the criteria, which have been mentioned by legislator in Clause I of Articles 12 and 80 of regulations of justice administrative court, may be embedded within the framework of legislation principle. The present research tries to express the aspects and criteria for annulment of government's approvals by general council in justice administrative court.
\end{abstract}

Keywords: Administrative judge, Justice Administrative Court, Governmental approvals, judicial supervision

\section{Introduction}

In the course of doing their tasks, the governmental officials shall inevitably approve the similar procedures, circulars, and regulations such as instructions and enforce them practically. This power was given by legislator to them. But these approvals may contradict to law and religion so it should be possible to control them because they are lower than law. With establishment of justice administrative court, IRI Constitution has predicted this possibility and it held that anyone may request justice administrative court for annulment of such regulations. Thus, justice administrative court shall request for addressing if anyone claims that the approvals of public officials are against law and religion (Sharia) and also issue the verdict for that matter. But there are many questions in this trend out of which the foremost one of them is: On which criteria can justice administrative court revoke government's approvals?

Many studies have been so far carried out concerning to judicial supervision over government's activities, particularly regarding the domain of competency of justice administrative court and its rule of procedures. The subject of annulment of governmental approvals will be studied with focus on votes of general council of justice administrative court in the present investigation.

\section{Judicial Supervision}

\subsection{Judicial supervision over administrative activities}

The relationship among people and government is one of the characteristics of law-centered government. The historical experiences signify that it is sufficient only to identify domain of powers to control rulers' behavior. Therefore it necessitates supervision permanently over domain of powers of rulers and quality of their performance through another institution. "Hence, no official and institution will judge about their own powers. Also, both the enforcement of regulations may be done arbitrarily or wrongly and their concept and limits can be variously interpreted. Perhaps the law may be executed and interpreted in such a way that a governmental official or public institution may move completely opposite to 
the objective of legislator and goal of law. Accordingly, there is no doubt about requirement for control and revision over powers and practice of governmental authorities and institutions (Rasekh, 2009: 25). The main subject is responsiveness to public decision-making in judicial supervision. Thus, judicial revision is not restricted to control and supervision over measures of the executive based on narrowed concept as one of governmental powers (Hadavand, 2007: 309). It can be mentioned that judicial supervision denotes the accurate analysis on decisions and measures of executive officials by the courts in order to supervise over observance of legal principles and rules. It has been proved by experience that the administrative and parliamentary supervisions have been mainly useful for evaluation on rate of advancement of goals and plans compared to addressing legal actions and pleas by persons from administrative system that characterized as an absolute legal right for individuals (Tabatabaei Motameni, 2008: 419). In present study, only judicial supervision over administrative activities of governmental authorities is taken into consideration. Thus, we do not deal with supervision over political, legislative, and judicial activities of governmental powers.

According to Article 170 of IRI Constitution: "Judges are obliged to refrain from enforcing the government's decrees and regulations, that are in conflict with Islamic laws and norms, or which lie outside the competence of the Executive. Everyone has a duty to demand the annulment of any such regulation from the Court of Administrative Justice." The supervision that has been predicted in this article possesses case aspect. Given this explanation that if during litigation of a case, the judge recognizes the documented procedure of parties of dispute as opposite to Islamic rules and regulations or beyond the limits of powers of the enacting official or institution of that approval and consequently avoids from its enforcement for the related case, such rejection is only limited to the given action and does not exceed from that matter it will be legally effective as long as the annulment of the given approval is not requested from justice administrative court by the related judge. Article 173 that deals with exclusive competency of justice administrative court in judicial supervision held as follows: "A court to be known as the Justice Administrative Court will be constituted under the supervision of the Head of the Judiciary in order to investigate the complaints, grievances, and objections of the people in respect of government officials, organs, and statutes. The jurisdiction, powers, and mode of operation of this court will be determined by law." As it mentioned at the end of this article, the law determines the limits of powers and method of action for justice administrative court. At present, 'Act regarding organization and rules of procedure for justice administrative court' (dated 13/12/2011) was enforced where some of its articles were recognized in compliance with expediency of legal system by The Expediency Council and then it became mandatory and binding after passing through the legal steps since August 2013. This institution has been assumed composing of courts of first instance, appeal court, general council, and specialized councils according to Article-2 of new regulation of this court and determination of judicial and administrative organizations and number of courts has been deemed as subjected to approval by head of the Judiciary. In a general perspective, Article 10 of new act has been stipulated to draw the limits of competency of justice administrative court and it determined as follows: addressing the complaints, pleas, and protests by natural persons or legal entities regarding decisions and measures of governmental units including ministries, organizations, institutions, public enterprises, municipalities, Social Security Organization, revolutionary organizations and institutions, and their affiliated instates, and definite decisions made by the councils for litigation of administrative violations and some commissions such as tax commission, laborer- employer dispute settlement board, commission for subject of Article-100 of act of municipalities, which exclusively lie within the competency of justice administrative court in terms of infringement of rules and regulations or in opposition to them and also addressing the complaints by judges and the parties included in national service administration law and other servants in public units whether military and state related personnel in terms of wasting their employment rights. The legislator has drawn the limits of competency for general council of this court in Article-12 of this act. According to this article, the limits of competency and powers of general council of justice administrative court are as follows:

1- Addressing complaints, pleas, protests of natural persons or legal entities from procedures and other public systems and regulations and municipalities, and non-governmental public institutes in the cases when the aforesaid regulations may lead to wasting rights of persons due to conflict with religion or law and or incompetency of the related body or transgression or abuse of powers or violation from enforcement of rules and regulations or avoidance from doing some tasks.

2- Issuance of uniform judicial precedent decree when it has been issued as contradictory verdicts from other branches of justice administrative court in similar cases.

3- Issuance of uniform judicial precedent decree about the same matter when numerous similar verdicts have been issued by branches of justice administrative court.

In this article, the appealing litigation of general council to final verdicts of litigation councils for administrative violations has not been mentioned and thus the actions relating to this matter lie within the competency of branches of this court by virtue of Clause-II of Article 10. 
The competency of general council for annulment of government's approvals possesses distinct feature for litigations in these branches and that is the condition for absence of plaintiff's benefit in action for annulment of administrative decision since as it asserted by Article 170 of constitution: "...Everyone has a duty to demand the annulment of any such regulation from the Court of Administrative Justice".

The administrative activities are deemed as subject of judicial supervisions in decision, which are made by intention to create legal relations and in order to create a legal status between parties and or amendment or revocation of the existing legal status among them and is converted into the origin for right and obligation in favor of or against them. These types of decisions are embedded generally and impersonally within the framework of administrative procedures, bylaws, and circulars and their verdict includes all persons and or a group of them and concerning to certain legal status. In Iranian legal system, Article 138 of IRI Constitution has stipulated the competency of making such decision for board of ministers, each of ministers, and commissions composed of several ministers; however, according to premise of Article 126 and Clause-III of Article 158, it can be implied that such a capacity is also devoted to president and head of Judiciary. It has been declared in a theory that: "In addition to the Cabinet and its members, the chairmen of public organizations and institutions possess such powers in their field of activity as well. despite of this fact that the aforesaid powers have not been anticipated in rules, at the same time the heads of independent public organizations and units such as Iran Central Insurance Company, Iran Telecommunications Company, State Organization for registration of documents and properties, and also other public legal entities including municipalities and national Islamic Councils possess the right of enactment of procedures and circulars and so forth." (Musazadeh, 2009: 113)

In Clause I of Article 12 of regulations of justice administrative court, addressing complaints, pleas, and protests of natural persons or legal entities from public procedures and other rules and regulations and municipalities lies within the competency and capacity of general council and implication of this phrase (other public rules and regulations and municipalities) signifies that the competency of justice administrative court in addressing public regulations is not only limited to a certain type of them and although Article 170 of Constitution deals with public procedures and bylaws, the public approvals are not only summarized in the aforesaid titles and it covers other rules such as procedures, instructions, and other ratified regulations as well so the legislator has referred to two aforesaid matters regarding issuance of verdict for the distinct persons. In other words, regardless of any title given to them, complaint from all approvals whether general and public type and concerning to uncertain parties may be heard and addressed in this court provided that they are assumed substantially as source of rule and regulation for which title of regulations apply to them (Sadrolhofazi, 1993: 451).

As a result, it may be mentioned that the public approvals or regulations comprise of a group of rules issued by explicit or implicit verdict of legislator and or based on the credibility of power caused by administrative responsibility by competent authorities (Musazadeh, 2005: 150). The Cabinet approvals, executive and independent procedures, and circulars and directives are assumed as types of public regulations.

\subsection{Judicial supervision strategies over administrative activities}

It is tried in this article to analyze the bases of judicial supervision under which the courts acquire the license for legal control over administrative activity. It can be expressed with this implication that such strategies are presented under titles of rule of law, separation of powers, and basic rights.

\subsubsection{Rule of law}

The rule of law is one of the fundamental concepts in public law. Limitation of power and determination of competency limits for each of political authorities and institutions and powers of each of officials are considered as the major guidelines in rule of law. Thus, the rulers should follow the criteria of public law in regulation of their relations with people. Overall, the approaches of rule of law may be examined in two procedural and substantial spectra:

In procedural approach, following of the statutory law or guarantee and enforcement of rule of law is considered as the foremost goal. From a general point of view, the characteristics of law can be divided into essential and accidental features. The essential features are those ones, which are assumed as basic conditions to convert a rule into a law (Markaz Malmiri, 2006: 55-58). The essential features are as follows: The law should be general, binding, explicit and obvious, relating to future, relatively constant and stable, and it should be publicly declared and approved by competent body. The accidental features of law are those attributes which may be called leniently as law even though a rule is excluded from them. These attributes may be implied as follows: responsiveness to requirements of community, reflective of opinion of majority, preparatory for public interests, morality-based, effective and pioneer (Rasekh, 2009: 26-34). 


\subsubsection{Separation of powers}

Primarily in necessitates for us to propose a brief prologue regarding fundamental principle of basic law and then imply its relevance with subject of judicial supervision. "As it has become prevalent in the west and many world countries today, the principle of separation of powers is deemed as achievement of Montesquieu the French thinker and philosopher at eighteenth century." (Ghazi, 2008: 164) The basis of his doctrine about separation of powers has formed in order to prevent from concentration of political power at the hand of a single person or group and avoidance from dictatorship and despotic rule. The Montesquieu's rule for separation of powers and criterion for measurement of tasks of political institutions is deemed as the foremost manifestation of governance i.e. law that is revealed in different forms of enactment, enforcement, and judgment based on law. The mutual relationship among separation of powers and judicial supervision may be proposed in role of separation of power in preparation of platform for judicial supervision and role of judicial supervision in protection from separation of powers.

\subsection{Judicial supervision models for administrative activities}

It can be mentioned that three models of French, British, and German judicial supervision are addressed in administrative law as a whole. The French model is close to functional approach and British model to right-based attitude while German model is deemed approximately as a hybrid model of two other models (Hadavand, 2011: 500).

Despite of the existing constraints in range of the supervised public officials and institutions, the regulatory principles and aspects, and weakness of public law approach toward the structure and rules of procedures in Iranian administrative proceedings, our model is close to German model from procedural aspect since the administrative litigation is only assumed as a judicial matter in Iranian legal system (Gorgi, 2008: 153). On the other hand, this judicial body possesses different structure from other administrative courts. According to Article 159 of Constitution, the justice courts are deemed as the general body to address complaints and litigations and according to Article 173, justice administrative court is assumed as an exclusive body. "The advantage of Iranian administrative litigation may be assumed in its organizational and functional independence from the Executive and the Legislature as manifestation of separation of powers; however, such independence should not convert the administrative litigation institute into an independent isle and make it far away from executive and administrative facts." (Gorgi, 2008: 153).

\section{Aspects of Judicial Supervision Over Administrative Activities}

After brief analysis on concept, fundamentals, and models of administrative proceedings, we should explore the aspects of judicial supervision briefly as well. In judicial supervision over administrative activity, the administrative judge should employ some causes by which s/he can measure that administrative action and then make decision. "One can observe in modern administrative law that the courts usually are involved in six major matters in the proposed administrative action: Firstly, has the administrative body violated from the competency that has been granted to it? Did it make wrong error in making decision? Was the decision-making mechanism rational? Was the process of decision-making fair? Are the results of administrative decision substantially rational? And or did process of decision-making or its outcome violate to human right or not?" (Halliday, 2004: 129, quoted from Emami, Vaezi, \& Suleimani, 2012: 296)

It should be acknowledged in position of analysis on regulatory criteria of general council in justice administrative court that 'all of regulatory aspects based on which justice administrative court is allowed to address decisions and measures of public bodies may be exclusively justified with resort to the statutory law approved in parliament and Islamic law and procedure of this court expresses this point since day of establishment that this institution could not create unwritten and undeclared principles.' (Zarei, 1998: 370, quoted from Emami, Vaezi, \& Suleimani, 2012: 302)

In general in domestic legal system, Clause I of Article 12 and Article 80 of new regulations of this court are deemed as the paramount legal articles regarding the aspects of annulment of executive regulations by general council of justice administrative court. In a general review of these articles, some subjects such as conflict among administrative activity and statutory law and religious criteria, exclusion of administrative official from its specific limits of competency, transgression and abuse of powers and wasting rights of parties may be assumed as the reasons and aspects of litigation in general council of this court.

\subsection{Non- contradiction to higher norms}

The legislation principle is supposed as one of the most fundamental and foremost principles in administrative legal 
systems. According to this principle, the public and administrative official shall respect all regulations over which they govern in making decisions and taking administrative measures. Accordingly, all administrative activities and measures are enforced within legal framework and they should be based on law (Hadavand \& Mashhadi, 2012: 86).

In fact, recognition and determination of legal rules governing over administrative official or institution and analysis of its nature of them is the first task for administrative judge upon judicial supervision over executive regulations. The rule of law in administrative activities signifies the reference nature of the governing legal rules and their sovereignty over administrative body and in modern administrative law, the governing legal rule over administration is not exclusively limited to the approved law by Parliament. The governing regulations over justice administrative court and thirty-year procedure of the regulatory institution may suggest that the compliance of governmental approval with statutory laws and religious criteria is deemed as the most prominent criterion for rule of law in administrative activity. Hence, based on the existing hierarchy between Iranian legal norms, the administrative activities shall not be contradictory to IRI Constitution, common law, and religious criteria.

\subsubsection{Non- contradiction to Constitution}

The question that may be raised about competency of justice administrative court in this field is that: Is competency of this court in addressing legislation of administrative activities included in Constitution as well? There is no doubt in lack of conflict between administrative decisions with Constitution. But there is some dispute about this point that which institution is responsible for protection from Constitution in administrative activities in terms of lack of explicit expression by Constitution. Four assumptions have been posited in this regard in each of each of which one of the following bodies have been mentioned as competent bodies.

1- Guardian Council; 2- Speaker of Islamic Parliament; 3- Justice administrative court and Guardian Council; and 4- Justice administrative court

In first theory, it is said that with respect to tasks and goal of formation of Guardian Council, this council is also responsible for control of superiority of Constitution over public regulations and approvals (Fallahzadeh; 2009: 27). It is implied in second assumption that with respect to Article 138 that assigned supervision over non- contradiction of the aforesaid approvals to speaker of Iranian Islamic Parliament, we should assume the control over originality of administrative approvals with detailed interpretation of terminology of regulations in this article in competency of parliament speaker (Tila, 2004: 60). It has been explained in third theory that the predicted mechanism may be enforced regarding legality of administrative decisions about originality of administrative decisions (Kadkhodayee \& Vijeh, 2009: 42). However, the last assumption attaches the competency of justice administrative court in control of administrative decisions regarding non- contradiction to IRI Constitution (Tila, 2004: 61).

Also in terms of lexical perspective, Article 170 of Constitution has considered absolutely the rules including basic and common law by employing term 'Islamic rules and regulations'. In addition, no one could accept that the administrative approvals may be against the Constitution and at the same time with respect to general competency of this court in addressing the action for legality of administrative decisions, according to opinion of author it is best strategy to assume justice administrative court as a competent body.

\subsubsection{Non- contradiction to common law}

Today, after Constitution as the superior norms in international treaties, the approved common laws by the Legislator is placed at next position in modern legal systems. Also the most prominent regulatory aspect and basis in justice administrative court is to consider the contingencies of statutory law, particularly the ordinary law or laws infringed by procedural activity of public officials. One of the results of principle of rule of law is that the government's approvals not to contradict explicitly or implicitly to ratifications of the Legislature (Sadrolhofazi, 1993: 445-446). The conflict between governmental approvals with ordinary laws has been reflected as a general principle and with different and several interpretations including lack of legal justification, opposition to legal principles and criteria, and lack of legal validation approximately in all votes of general council of justice administrative court where they have been issued for annulment of decisions and activities of administrative officials (Hadavand \& Mashhadi, 2012: 89). Multiple legislating bodies in our country have made justice administrative court in some cases to address the governmental regulations in conflict with approval of Expediency Council as well. For example, within the judgment no 213 dated 02/07/2006 regarding request for annulment of approval no 19-1/81085 dated 03/08/2005 of supreme administrative council, the general council of justice administrative court address the claim for contradiction of this approval with provision-2 of the single article in Act concerning to amendment of Governmental Discretionary Punishments Law ratified by Expediency Council and 
eventually has not assumed it as examples of infringement of approvals of this council. The contradictory governmental approvals can be examined under several titles such as administrative activities as opposed to goal and verdict of legislator, non-observance of legal formalities in decision- making, and non- observance of time domain specified by legislator in making decision.

\title{
3.1.2.1 The administrative activities against goal and verdict of legislator
}

With enactment of rules, legislator follows some objectives where their realization is subjected to pursuance of law by the enforcers and compliance of their measures with the given regulation. Otherwise, in order to protect from principle of rule of law, administrative judge may annul the contradictory administrative activity to goal and verdict of legislator. The justice administrative court has addressed the observance of the stipulated goal by executive official in law within several votes and issued the verdict for them. For instance, judgment no 203 dated 22/06/2008 as subject of litigation of supreme audit court in annulment of Clause-II of approval no 31657T/28576 ratified by Board of Ministers (Cabinet) on 01/08/2005, justice administrative court holds:

"... By virtue of Article 10 and 11 of state employment act or mission of governmental servant to other ministries and public institutions and or dispatching them to pass training or apprenticeship courses inside and outside country, and with observance of the related regulation prescribed to officials and transference or mission of contractual servants or dispatching them to pass training or apprenticeship courses inside or outside the country contradicts to goal of legislator for their employment to assume temporary and certain tasks within the limited and definite period of time. Thus, Article 21 of amendment of contractual employment procedure is recognized as contradicted to the law based on which it is permitted to transfer and send the contractual employees for mission to other public organizations and institutions and or to send them to pass training and or apprenticeship courses inside or outside the country and it is annulled by virtue of second part of Article 170 of IRI Constitution and Article 1 and Clause-I of Article 19 and Article 42 of justice administrative court Act."

Similarly, Judgment no 57 dated 22/06/1996 states:

"As per verdict of Article 217 of Direct Taxes Law, 1\% cost of collection of taxes and fines has been stipulated in special cases including payment of bonus to encourage personnel who act efficiently in tax collection, deprivation of such personnel lacks legal permission only due to administrative conviction and for this reason, Clauses 19 and 20 in confidential circular no 421 dated 11/05/1994 of Ministry of Economy and Financial Affairs is deemed in conflict with the given article in terms of non-compliance with goal of legislator with the stipulated verdict in above-said article and it is annulled by virtue of second part of Article 25 of justice administrative court law."

\subsubsection{Non- observance of legal formalities in administrative decision- making}

It is completely obvious that the administrative authorities should observe the predicted procedures and formalities upon making decisions. In this regard, in annulment of Clause I of Article 5 in procedure of taxation boards, judgment no 280 dated 03/10/1999 holds:

\begin{abstract}
"Whereas the verdict of legislator as it stipulated in Art 43 of Social Security Act approved in 1975 and its later amendments signify the requisite for establishment of premium claims audit boards with certain number of agents from natural person and legal entities listed in the given article, Clause 1 of Article 5 of the protested procedure is in conflict with explicit verdict of legislator in this regard in terms of reducing number of members in the aforesaid board. Thus, on the strength of second part of Article 25 of justice administrative court law it is annulled."
\end{abstract}

\subsubsection{Non- observance of the time domain specified by legislator in making decision}

The legality of administrative activity requires observance of all rules and regulations of law including the stipulated time limit for its enforcement. Now, if administrative official overlooks legal deadlines and making decision and or execution of administrative measure out of the time limit specified by the legislator, it will be assumed as aspects of annulment of government's approvals. The justice administrative court has addressed this issue in some awards: In judgment no 382 dated 09/10/2005, general council of justice administrative court has not assumed exclusively postponement in codification and ratification of executive procedure of an act as contradiction of the disputed approval to law and or its exclusion from powers of the Executive in enactment of public regulations. 


\subsubsection{Non- contradiction to religion (Sharia)}

The necessity for non- contradiction of administrative decisions to Islamic criteria has been addressed in Article-4 of Constitution. After expressing the requisite of compliance of rules and regulations with religion (Sharia), it is mentioned in this article: "...the duty to ascertain this matter devolves on the jurists of the Guardian Council." In Article 170, the judges in justice courts have been required to avoiding from enforcement of approvals against religion (Sharia). But justice administrative court has been introduced as the body for annulment of approvals against Sharia. Whereas both Guardian Council and justice administrative court have been assumed as competent in this regard thus in Article 87 of regulation of this court a mechanism has been considered according which these two body may cooperated with each other in annulment of administrative decisions against Sharia.

There are different opinions over role of justice administrative court along with Guardian Council in addressing the claim for opposition to Sharia. According to an assumption, there is a relationship among Guardian Council and justice administrative court in which Guardian Council act as an expert for justice administrative court but such an assumption completely contradicts to the requirement of this court in pursuance to comment of Guardian Council (Darvishi, 2009: 261). In another theory with respect to Article 41 of former law of justice administrative court, this body has been only introduced with its administrative role. According to their beliefs, both bodies have been ignored in this article (Savadkoohi, 2001: 4). It has been mentioned in another paradigm that: The given action includes two judges where one judges based on substantial rules and for this reason s/he is called substantial judge while the other judge that often guarantees enforcement of procedural rules (rules of procedure) so s/he may be assumed as procedural judge for action (Vaezi, 2009: 135). Author argues that in the latter theory the position of both bodies has been considered better and it seems more logical. The point that may be posited about Article 87 of justice administrative court Act is that the jurists of Guardian Council address the legitimacy of the disputed approval and recognition of this matter in terms of administrative and legal aspects is excluded from their competency.

The method of religious supervision by jurists of Guardian Council over governmental approvals is also different from the ratified laws by parliament so that the governmental approvals are enforced after ratification and at next phase if it is complained about their contradiction to religion (Sharia) in justice administrative court, the court shall send this matter to Guardian Council for comment. Of course, in this regard, statutes of public organizations, enterprises, and institutions or affiliates to government shall be excluded according to second part of Article 85 of Constitution that has been approved permanently by Board of Ministers and parliamentary permission.

Regarding religious criterion of supervision and based on interpretive doctrine no 2437 dated 01/01/1985 about Article 96 of Constitution, Guardian Council has held: "... ascertainment of its concordance with the Constitution rests with the majority of all members (jurists) of the Guardian Council." In line with this doctrine, jurists of Guardian Council may consider fatwa of majority of council members in Islamic nature of regulations as criterion and renounce the opposite approvals to fatwa of their majority. (Salehian, 2013: 50-51). Alternately, the conduct of Guardian Council in action of legitimacy of administrative regulations signifies that jurisprudential comments from Supreme Leader have also special position in juristic comments in Guardian Council. For instance, awards no 363 dated 24/10/2004, no 364 dated $14 / 08 / 2007$, and no 353 dated 12/08/2007 issued by general council of this court are some of examples in this sense.

\subsubsection{Competency principle and its relevant cases}

Of other aspects of judicial supervision, which have been implied in the relevant rules in justice administrative court, is exceeding administrative official from his competency limits. The most major features of competency are its legality, exclusion, requisite, and limitation. In a general classification, the public lawyers have divided the competency of administrative officials into two obligatory and arbitrary categories. The obligatory competency is a matter in which the legal rule compels the administrative authority to do a task by a certain method (Ghazi, 1996: 53) and in contrast the arbitrary competency is a type of competency that allows the administrative official to have relatively freedom of action and power for maneuver and enables him/ her to make the most appropriate decisions among different reasonable legal decisions (Research group, 2008: 8). In fact, arbitrary competency is a power given to an administrative officer thereby s/he can fill the gap among fact and law and adjust the law with facts (ibid, 9). Devolution of arbitrary competencies on administrative authorities will be followed by probable abuse of powers and deviation of administrative bodies. On the one hand, the subject of organization of competencies is posited in modern administrative law and on the other hand the tools and bases of judicial supervisions have been expanded with developing concept of legality of administrative activity and exceeding the limits of powers as well.

Now, exceeding from limit of powers as well as lack of competence are some other cases, which have been 
assumed as reasons for annulment in many awards by justice administrative court. One of the examples for exceeding from limit of powers and lack of competence is to enter in field of legislation and or interference in competencies and powers of the Judiciary where it is in fact considered as ignoring principle of separation of powers as well. (Suleimani, 2012: 349).

There are many examples among awards of justice administrative court in which the administrative approvals have been annulled due to their conflict in two legislation and judicial fields out of them one can refer to judgment no 373 dated 13/12/2004, judgment no 323 dated 21/11/1999, and judgment no 352 dated 12/08/2007.

Thus, interference of the Executive or some administrative officials of the Judiciary in those activities, which are related to other powers, has been assumed as a reason for annulment of approval. With respect to what it mentioned, legality, legitimacy, and competency of issuing official and observance of limits of powers and formalities are considered as important aspects in addressing procedure in justice administrative court.

\section{Conclusion}

The judicial supervision over administrative activity and annulment of error of administrative officials deviated from rules of public law in decision making requires the plaintiff and administrative judge to resort to criteria and causes based on which the given action is measured and the governmental regulation is annulled by virtue of infringement of those criteria. These principles and criteria are called aspects of judicial supervision. In domestic legal system, Articles 170 and 173 of IRI Constitution realized judicial supervision over administrative activities of government with establishment of an institution called justice administrative court. The subject of present research was regulatory aspects and criteria for annulment of governmental approvals by general council of this court. The most outstanding legal cases about aspects of annulment of government's approvals by general council of justice administrative court is first clause of Article 12 and Article 80 of justice administrative court Act. In a general approach from terms of these articles, the cases of contradiction of administrative activity to law, religious criteria, exceeding administrative authority from limits of his/her competency at stipulated status, and violation or abuse of powers may be assumed as aspects of addressing and adjudication by general council of this court against transgressions by public officials. The secured field from judicial control of justice administrative court is a domain that is used by public officials in employing arbitrary competency. A wide range of decisions of public officials lies within this type and the maximum capacity for wasting rights and freedoms of citizens by public authorities caused by this type of legal powers. In enforcement of arbitrary competencies, there is less possibility and even no possibility for judicial supervision. The presence of current aspects of judicial supervision by justice administrative court that is generally returned to obligatory competencies of administrative officials and procedural litigation may seem inadequate in realization of efficient judicial supervision over government's activities.

\section{References}

Emami, Mohammad \& Ostovar Sangari, Koorosh (2009), Administrative law, 9th Ed, Tehran, Tehran: Mizan Pub

Emami, Mohammad \& Vaezi, Seyed Mojtaba \& Suleimani, Mahasti (2012), Regulation for referable actions in justice administrative court, $1^{\text {st }}$ Ed, Tehran: Mizan Pub.

Darvishi, Babak, (2009), The body for annulment of governmental bylaws and procedures contradicted to religion criteria; Guardian Council or justice administrative court, A collection of articles posited in justice administrative court conference: judicial competency and administrative proceedings, 1'st Ed, Tehran Islamic Azad University.

Rasekh, Mohammad (2009), Supervision and balance in basic law system, $1^{\text {st }}$ Ed, Tehran: Drack Pub.

Sadrolhofazi, Seyed Nasrollah, (1993), judicial supervision over government's activities in justice administrative court, $1^{\text {st }}$ Ed, Tehran: Shahriar Pub.

Tabatabaei Motameni, Manoochehr, (2008), Administrative law, 14 $4^{\text {th }}$ Ed, Tehran: SAMT Pub.

Ghazi, Seyed Abolfazl (1996), Articles on public law, 1 ${ }^{\text {st }}$ Ed, Tehran: Dadgostar Pub.

Ghazi, Seyed Abolfazl (2008), Requirements of basic law, 32nd Ed, Tehran: Mizan Pub.

Kadkhodayee, Abbas Ali \& Vijeh, Mohammad Reza (2009), Guardian Council and the actions relating to annulment of governmental decisions against constitution, in a collection of articles posited in justice administrative court conference: judicial competency and administrative proceedings, $1^{\text {st }} \mathrm{Ed}$, Tehran Islamic Azad University.

Gorgi, Ali Akbar (2009), Approach to basic law, 2nd Ed, Tehran: Jangal Pub.

Mahmoudi, Javad (2011), Analytical study on administrative proceedings in Iranian law, Tehran: Jangal Pub.

Mahmoudi, Javad (2011), judicial supervision over governmental regulations in UK and France, $1^{\text {st }}$ Ed, Tehran: Jangal Pub.

Markaz Malmiri, Ahmad (2006), Rule of law (concepts, bases, and approaches), $1^{\text {st }}$ Ed, Tehran: Parliamentary researches center Pub.

Musazadeh, Reza (2005), Administrative law, $7^{\text {th }}$ Ed, Tehran: Mizan Pub.

Hadavand, Mehdi (2011), Comparative administrative law, vol. 2, 2nd Ed, Tehran: SAMT Pub. 
Hadavand, Mehdi \& Mashhadi, Dr. Ali (2012), Principles of administrative law in light of justice administrative court awards, $2^{\text {nd }}$ Ed, Tehran: Khorsandi Pub.

Hashemi, Seyed Mohammad (2004), Basic law in Islamic Republic of Iran, $2^{\text {nd }}$ vol., $9^{\text {th }}$ Ed, Tehran: Mizan Pub.

Aghayee Togh, Moslem, (?), Fundamentals and nature of judicial supervision over government's activities: A comparative studies in France, UK, and US, Research letter of juristic and legal deputy of strategic researches center, 1'st year, vol. 1

Tila, Parvaneh (2004), Judicial interpretation of constitution in justice administrative court procedure, Journal of legal researches, vol. 5

Rasekh, Mohammad (?), the essential and accidental features of law, Journal of Parliament and research, 13 ${ }^{\text {th }}$ year, vol. 51.

Savadkoohi, Sam (2001), Comparative analysis of competent legal body for infringement of governmental approvals, Journal of proceedings, vol. 26

Fallahzadeh, Ali Mohammad (?), Position of justice administrative court in IRI Constitution, Research letter of juristic and legal deputy of strategic researches center, $1^{\text {st }}$ year, vol. 1.

Gorgi, Ali Akbar (2008), Rule of law and constraints of litigation rights in justice administrative court, Journal of basic law, summer 2008, vol. 9.

Public law researching group in deputy of legal and parliamentary affairs of presidency, execution of arbitrary competencies by administrative authorities, Quarterly of legal communication, $6^{\text {th }}$ year, vol. 13, spring 2008

Vaezi, Seyed Mojtaba (2009), the role of justice administrative court in legal proceedings for administrative regulations, Journal of legal studies on Shiraz University, $1^{\text {st }}$ series, vol. 3, winter 2009.

Vijeh, Mohammad Reza (2012), the judicial supervision by justice administrative court over executive regulations, Quarterly of legal research, $14^{\text {th }}$ year, summer 2012, vol. 37 .

Hashemi, Seyed Mohammad (2003), Human Rights supports and guarantees in domestic law and international system, Journal of legal studies in Faculty of Law in Shahid Beheshti University, autumn and winter 2003, vol. 38.

Hadavand, Mehdi (2007), Control of power and its development in administrative law, Journal of basic law, 4th year, vol. 8, summer 2007.

Hadavand, Mehdi, (2008), judicial supervision, conceptual analysis, basic developments, Journal of basic law, summer 2008, $7^{\text {th }}$ year, vol. 9.

Hadavand, Mehdi (2009), the criteria for favorable administration and development of administrative law: conceptual analysis, Journal of legal studies, Monograph no 1, spring \& summer 2009.

Salehian, Najmeh (2013), Role of justice administrative court in legitimate supervision over administrative regulations, MA thesis of public law, Faculty of Qom, Tehran University, April 2013 